\title{
England, Sir Martin Gilbert and Hungarian State Security
}

Krisztián Ungváry

National Libray István Széchenyi, Budapest; e-mail: kungvary@gmail.com

This is an Accepted Manuscript of an article published by Taylor \& Francis in Journal of Intelligence History on 04/08/2015, available online:

http://www.tandfonline.com/10.1080/16161262.2015.1061796.

Abstract (100-150 words):

The article tells us the story of a bungled attempt at recruitment of a prominent member of the British establishment by the Hungarian Foreign Intelligence Service in the 60s. Its research was based on files found in the Historical Archives of Hungarian State Security. As the reports might have been "edited", fabricated and tailored for the superiors, the author went to great lengths to study all of the volumes of files dealing with the case, and, using judicious vetting, composed a very credible story of this intelligence operation. The case study successfully lifts the veil of secrecy over sources and methods of the then Hungarian intelligence service and even manages to name a wellknown Hungarian person as an agent and talent-spotter. As it turns out. the target proved to be far more skillful and resourceful than his would-be recruiters and took full advantage of their eagerness for his own material benefit without delivering any intelligence of value. The author suspects that the Hungarians' target was a plant of MI5, which frequently used double agent operations against the Eastern services. In closing, the author, however, finds it strange that the well-known target never mentioned or hinted at the incident in any of his writing, though he could have been quite proud of his feat of making a fool of a hostile intelligence service.

Key words: recruitment, double agent operation, MI6, Hungarian Intelligence, Martin Gilbert 


\section{Introduction}

Between its establishment in 1950 and its complete compromise in 1965, the London "residentura" ${ }^{1}$ was the most important foreign base of the Hungarian intelligence services. For fifteen years its officers spared no expense of effort to recruit informants among the English political elite and in the Hungarian émigré community. While they could chalk up some successes in the latter, they met with practically total failure in "high society." The reasons for this failure lie partly in the incompetence of the intelligence officers and partly in the efficiency of British counterintelligence.

Among the individuals analysed in the course of intelligence operations directed against Great Britain, Martin Gilbert was by far the most important. This is shown by the fact that the Historical Archives of the State Security Services (Állambiztonsági Szolgálatok Történeti Levéltára - ÁBTL) in Budapest holds five volumes of documentation on Hungarian State Security's contacts with Gilbert, to a total of 701 pages. This makes Gilbert the bestdocumented English personality: the material on most candidates for recruitment fills just one volume (150 to 250 pages); two volumes are rare, and there is only one person with three volumes.

The Gilbert case deserves analysis for several reasons, and his status as a public figure today is not the most important by far. As Gilbert was already considered a great catch in 1960, all resources were mobilized to study him and win him over. Therefore we can discover the methods of Hungarian State Security through the Gilbert files. Additionally, we can learn what interested the Hungarians in this period, and what they expected from their intelligence operation in England. Yet another dimension of the story is the fact that the discovery of the "Cambridge Five" network coincided with Gilbert's recruitment. Unfortunately, British counterintelligence materials are not open to researchers. ${ }^{2}$ But we can surmise that the British did not sit idly by: more than likely they initiated dangle operations on numerous occasions. For the time being only the Hungarian documentation of Gilbert's story is open to researchers, but this is sufficient to draw conclusions on the activities of the opposing services.

\footnotetext{
1 "Residentura" is originally a Russian term for a clandestine intelligence station - often under diplomatic or commercial cover - deployed in a target country. The term was also adopted by the member states of the Warsaw Pact. László Szabó, Second Secretary at the Hungarian Embassy and the resident's deputy defected to the Americans in 1965, and "burned" the entire resident's office. After this there was no serious attempt to upgrade Hungarian intelligence operations in London until 1990.

${ }^{2}$ Christopher Andrew: The Defence of the Realm. The Authorized History of MI5 (Allen Lane Penguin Books 2009) can be considered the only "official" work.
} 


\section{The Sources and their Reliability}

Since the operational documents of our subject can be studied only in the Historical Archives of the State Security Services, we must also address the evaluation of this set of sources. In the course of intelligence operations directed against Great Britain, the Hungarian services identified and seriously analysed at least 150 English individuals as potential recruits. Unlike Gilbert, most of these had some Hungarian relatives, or were themselves Hungarian émigrés. In response to search terms referring to "England" the search engine of the ÁTBL identifies 142 files on recruitment attempts (successful recruitments are not included). However, the keywording is incomplete, and 30 percent of the files were destroyed at the time of regime change, while 10 percent are still in the possession of the successor services and therefore not open to researchers. ${ }^{3}$ Of the materials on the agents recruited and exploited in England, four folders on recruitments and eleven on exploitation were deposited. Additionally, the overwhelming majority of the materials generated by the London residentura between 1950 and 1965 - a total of 11 folders and several thousand pages ${ }^{4}$ - were also deposited in the archives. From these almost the complete range of the residentura's activities and nearly all the agents can be identified.

The question of how authentic the documents of the state security archives are must be addressed. Since they have not been manipulated since the regime change, they are certainly genuine. Consequently, their contents reflect the understanding of Hungarian intelligence officers of the period. In many respects their perspective and interpretation requires a critical approach - but this is true for other sources as well. But we can be certain that at the time the documents on the Gilbert case were created they did not contain any falsification on the part of the state security officers. Since they were created for internal use only, and several individuals - up to department chiefs - were involved in verifying them, we can exclude the possibility that anyone would risk a slanted presentation of the facts. This does not necessarily mean that the information the intelligence officers received from Gilbert reflected reality (I address this in some cases). But it is certain that what is in the files did take place and did get said - as it is verified by the surveillance initiated on Gilbert, the inspection of his mail and the wiretap of his conversations. My essay undertakes to show only the "Hungarian version" of the Gilbert story. There are two reasons for this. First, the way Gilbert presented himself and

\footnotetext{
${ }^{3}$ The author obtained this information while serving as a member of the committee investigating the fate of state security documents in 2008.

${ }^{4}$ OL-003-8/I-XI. The author's essay on Hungarian intelligence operations in England is under consideration for publication in Hungary.
} 
the actions of the Hungarian officers are interesting in themselves. Second, the British intelligence documents related to the case are not yet available to researchers.

\section{A Personal Remark}

The reader may well ask what Gilbert himself thinks of about all this. For several reasons I did not consider it important to ask him. First of all, because the basic question is whether it was under orders from the British intelligence services that Gilbert came into contact with Hungarian intelligence - and Gilbert could answer this question truthfully only if this was not so, otherwise he would be bound by his oath of secrecy. The operatives of MI6 or MI5 are not in the habit of publicly disclosing their affiliation when asked. And also because whatever transpired, Gilbert made a fool of a Communist state security service, so he cannot be accused of being a traitor. From this aspect the story can only reflect positively on him.

I must also add that the authors of political biographies do not always consider it necessary to ask their subject for his opinion of what is published about them. A historian must be much more aware than the general public that for various reasons his actions may be examined. These are major considerations when the person in question is active both socially and politically. We feel that these preliminary remarks were necessary, since the subject of our research is the connection between the British historian Sir Martin Gilbert and Hungarian State Security.

"One of the modern world's leading historians" - claims Sir Martin Gilbert on his own homepage, and this statement is completely true. ${ }^{5} \mathrm{He}$ is the official biographer of Winston Churchill, and a specialist on the Holocaust and on the history of the Jewish people and Israel. $\mathrm{He}$ is also the author of more than eighty books that have received international acclaim both among historians and from the general public. Sir Martin entered the political scene in 2009, when he answered then-Prime Minister Gordon Brown's request to become a member of the Chilcot Committee, charged with investigating the background of Great Britain's involvement in the 2003 Gulf War. At the same time he became a member of the Privy Council as well. These circumstances further emphasize why the state security case study is of interest today.

\section{The target person}

\footnotetext{
${ }^{5}$ Sir Martin Gilbert's homepage can be found under http://www.martingilbert.com/
} 
The Gilbert case started in 1958. Gilbert was a student at Oxford University, and during a conversation he spoke with one of his fellow students, Ashok Nehru, about his plans to visit India. Nehru made him promise that Gilbert would visit his mother in Delhi. ${ }^{6}$ Ashok Nehru's mother had been born into a wealthy Jewish bourgeois family in Budapest in 1908 as Magda Friedmann. She was studying in England when she met Braj Kumar Nehru. Nehru, who was studying law and intended to pursue a political career, came from India's most influential family, which gave such politicians to India as Kumar's cousin, Jawaharlal Nehru, leader of the independence movement and later India's first prime minister, and his successor (and daughter), Indira Gandhi. Nehru and Friedmann were married in 1935, and moved to India. Probably due to her husband's political career and his connections, she was employed under the code name "Nimród" by Hungarian intelligence as a "social contact" after 1953. According to a memo dated 1961 "she gave no valuable information." ${ }^{7}$ It was not her, but her guest Ödön Kallós who drew the attention of the services to this gifted young man .

According to Gilbert, Friedmann (whom he would later call "Auntie Fori" or "my Indian aunt") did not disclose her Jewish origins to him for fifty years, even though he was also a Jew and in the meantime he became a world-famous researcher of Jewish history. Supposedly this belated discovery motivated him to publish his correspondence on Jewish history in a separate volume. ${ }^{8}$ This is all rather odd, not only because Friedmann's last name could not have left much doubt about her origins, and in Gilbert's case the reports by State Security emphasized his "Semitic characteristics" Additionally - as will be discussed later - on one occasion Gilbert visited Friedmann's family in Budapest.

Gilbert was spotted as a potential agent by Ödön Kallós, ${ }^{9}$ who worked undercover in various capitalist countries and reported under the code name "Barabás." In his report dated 9 September 1958 he wrote: "Although he came to know Ashok Nehru at Oxford, Gilbert has sharply criticized all three Nehru brothers for studying in Britain and in the US instead of at famous Indian universities. His general way of thinking and his behavior are characterized by being contrary to everything conventional. (...) His young age may make him especially interesting for us, because it is likely that the English Intelligence Service did not pay serious

\footnotetext{
${ }^{6}$ Martin Gilbert, Letters to Auntie Fori. 5000 Years of Jewish History. (Phoenix \& London, 2003), XVI.

${ }^{7}$ Ibid. XV.-XVI. ÁBTL K-184/IV., p. 165. Otherwise Magda Friedmann is not mentioned in the State Security Services' Archives, her file is presumed to be lost.

${ }^{8}$ Letters to Auntie Fori, XV.

${ }^{9}$ Ödön Kallós (1917-1986), economist, graduated in Great Britain. Chairman of the Chamber of Commerce between 1959 and 1981, then (until his death) Associate Chairman. The circumstances of his recruitment and the details of his service as an agent have not yet been analyzed.
} 
attention to him due to a lack of time. I request permission to start a general philosophical correspondence with him, in order to establish a contact." 10

"Barabás's" idea was approved; correspondence was started and became increasingly friendly. State Security had no serious networks of non-Hungarian agents in England in this period, so it had high hopes. Captain Péter Szikla ${ }^{11}$ approved Gilbert's (codename "Pandit") development plan on 5 February 1960. According to the plan either (a) after a year's pause "Barabás" would contact Gilbert again and would suggest a meeting during the Leipzig Fair, or (b) an operation officer would be introduced into his circles. It shows the thoroughness of State Security that that a whole year was allowed for the process.

"László Nagy,"12 an operative serving in the London residentura, reported on 3 November 1960 that on 25 October 1960 he made contact with Gilbert (renamed "Pártos," which roughly translates as "Biased" or "Partisan"). He also reported that their next meeting would be on 12 November 1960 in the "Simpson" restaurant, where Nagy would also receive the reply to "Barabás." The Hungarian intelligence officers considered the likelihood of British intelligence controlling Pártos, but they never thought of him as a double agent. If he were proven to be controlled, they planned to cancel the recruitment process and exploit him solely as a "social contact." This clearly shows the fine distinction between the two categories. "Social contact" is a formally legal and completely unregulated activity that is theoretically not prohibited in any country. On the other hand, recruitment was an unambiguous employment relationship between State Security and the agent. The intelligence branch obtained most of its information using this "dark" method (as it was dubbed in Service jargon) where the informant formally did not know who the recipient of the information was. Nagy and "Pártos" finally met on the 11th, one day ahead of schedule, since Gilbert had requested to move the appointment up one day. After the meeting Nagy recommended further "analysis."

The next meeting took place on 15 February 1961. According to Nagy's report: "I told Pártos that I was there primarily not to talk about the letter, but to ask some questions. He accepted my approach in a friendly manner, and we talked for more than two hours. (...) During the conversation he suggested a personal visit to Hungary during the summer, not for

\footnotetext{
${ }^{10}$ ÁBTL K-184/I., Report, 9 September 1958., p. 19.

${ }^{11}$ From 1955 Peter Szikla (later Peter Szolnok) (1928- ?) was the residentura's senior officer as well as first secretary of the embassy. In April 1958 he was expelled from Great Britain as a result of a successful dangling operation by British intelligence. After this he served in state scurity's central offices, and in 1965 he became Consul in Rio de Janeiro.

${ }^{12}$ His real identity could not be established.
} 
a vacation, but in order to obtain first-hand political experience. He has already visited Poland and Bulgaria this way. After his return he would talk about his positive experiences at various venues. He said he could cover his travel expenses, but may require some help with accommodation expenses. He suggested that he could ask "Barabás" to put him up if he would be in Budapest at the time. I declined to give him a straight answer but promised to contact "Barabás" on this issue."

During the conversation Gilbert claimed to be an organizer of the CND (Campaign for Nuclear Disarmament) protests. This gave further value to Gilbert's person for State Security, since CND and the leader of an affiliated movement (Direct Action), Professor Bertrand Russell, could be exploited to destabilize Britain's internal political situation. CND and DA were movements with the greatest mass support at that time: they had a combined membership of 500,000 compared to the British communist party's 30,000.

Captain Sándor Suszta ${ }^{14}$ prepared a new development plan on 10 May 1961, in which an invitation to Hungary was decided upon.

On 31 May Nagy again met "Pártos," whose behavior clearly indicated that he was offering his services. On 5 June 1961 Sándor Suszta made a special recommendation to invite "Pártos," and nominated Major Peter Szikla to serve as case officer. On 12 July Nagy gave "Pártos" a letter of invitation from "Barabás". The detailed, day-by-day schedule of the visit was ready on 11 August. Lieutenant Colonel Béla Szöke attached the following remark: "This plan is essentially the "minimal program." (...) As it is being executed, our experiences have to be analyzed at least daily, and the method of execution of pre-determined tasks, their modification or acceleration must be decided accordingly. "15 One can understand Szöke's enthusiasm: it seemed that Gilbert had, or was likely to acquire, serious contacts at the highest levels of British politics. In this State Security was not mistaken.

\section{Visit to Budapest}

Gilbert gladly accepted Barabás's invitation. His arrival, according to Suszta's report, happened as follows: "In accordance with our invitation, Pártos arrived in Budapest at 19.30 on 9 September 1961. Major Péter Szikla and the wife of covert agent Barabás (cover name) went to receive him, but they missed him at the station, so they met him only in Barabás's

\footnotetext{
${ }^{13}$ ÁBTL Vol K-184/I., pp. 67-68.

${ }^{14}$ Sándor Suszta (1930. január 1- ?) served in the intelligence center's England department at the time.

${ }^{15}$ ÁBTL Vol K-184/1, p. 117.
} 
apartment. "Mrs. Barabás" introduced Comrade Major Szikla to "Pártos" as a friend and colleague of her husband, and asked him to show "Pártos" around Budapest, while her husband was away. She also informed "Pártos," that her husband had to go abroad unexpectedly, and would return only on the 13th or 14th.

"Pártos" - according to general custom - inquired about Comrade Major Szikla's background. Comrade Szikla told him, that he was also working for the Chamber of Commerce, at the Market Research Department, and dealing mainly with English-speaking countries. Here "Pártos" interrupted him with the remark, that 'then our discussions will be useful to you, because I know a lot of things that you may find valuable.'

They talked for about an hour in the "Barabás" apartment. Meanwhile, an unexpected guest arrived, so Comrade Major Szikla recommended that they go to dinner, then "Pártos" should check into his hotel. "Pártos" was a little surprised at this - he may have expected to stay in the "Barabás" apartment - but went willingly."16

Szikla's report of 14 September details subsequent events: "I informed him that based on "Barabás's" permission, I was relieved of my duties at work, and could escort him all day during the following week. (...) I took "Pártos" to Fishermen's Bastion to introduce him to Budapest at night. Then we went to a restaurant on Hármashatár Mountain for dinner. He was impressed by the outings, and appreciated both. As a result of good food and drink his mood became quite relaxed, and we had a long conversation. (...) On his part, he said he hated the government currently ruling England, all of its institutions and all of its representatives. He claimed political motivation, which was rooted in personal grievances. He said that his years of military service in particular turned him against the system, because there he experienced the reactionary, demeaning and class-based policies that are the primary characteristics of that imperialistic country that is condemned to die. In his opinion, the rulers of England today are the representatives of political gangsterism, who, relying on the power of capital, are attempting to push aside all honest people, promote only their own class interests, and will sooner or later bring disaster on the country (...)

Getting acquainted went smoothly. In my judgment there will be no obstacles to further smooth contact and work. ${ }^{17}$

Péter Szikla devoted considerable effort to discover "Pártos's" political motives. According to Gilbert's response "He got his political views from his father, who had been a

\footnotetext{
${ }^{16}$ ÁBTL Vol. K-184/II., Report 11 September 1961. p. 19.

${ }^{17}$ ÁBTL K-184/II., Report 14 September 1961.pp. 22, 27.
} 
miner in Wales. (...) As a result of his indoctrination by his father, he also considers himself a Communist - said Pártos - although due to conditions in England, he has never said so publicly, and for tactical reasons he has denied it on occasion. But in fact he considers himself a Marxist-Leninist, accepts the theory of the class struggle, the necessity of the revolt of the proletariat (for example he does not agree with the notion that socialism can be instituted in a country without armed struggle, etc.) In his opinion it is not necessary to wait for such pre-conditions of the socialist revolution as the trust of the majority of the population, or the maturity of the political situation for an insurrection, since these never existed anywhere, and never will. It is enough for a smaller group of politically well prepared and militarily trained people to initiate a movement, or take in hand a revolt already in progress, become its leaders, and lead the masses to obtain the achievements of the proletarian revolution. To prove his point, he mentioned that he had prepared a plan for seizing London in the course of an insurrection. He had prepared the plan on the basis of the principles he had read in the works of Lenin.

(...) his other significant activity concerns West Germany. In the course of the last three years he considered it one of his most important tasks to fight against reviving fascism. He selected this field of activity partly due to personal reasons (he did not go into details about these), but for the most part out of political consideration. The conclusion he had drawn from his study of history also motivated this activity. From these it became obvious to him that both in the past and at present the foundation of Anglo-German cooperation has been opposition to the Soviet Union (...) He has collected data and documentation that proves that in Hitler's rise to power, in Germany's preparation for war, in the attack on the Soviet Union, the reactionary English government played a decisive role, and bears a heavy responsibility for World War II. (...) He prepared three revealing books from the material, which he considers extraordinarily valuable. He already has publishers for the books. ${ }^{18}$ The three subjects:

1. Plans for a joint Anglo-German empire

2. Behind-the-scene secrets of Munich

3. Why did Hitler turn on England

He mentioned in passing that he would like to lecture Hungarian experts interested in these subjects. (...) However, he requests that only trustworthy comrades should attend, since some of the materials he intends to use are confidential documents of the Foreign Office, and their disclosure to unauthorized persons is forbidden.

\footnotetext{
${ }^{18}$ There is no evidence at all that the volumes were ever finished and published.
} 
The other area of his activities is uncovering fascists who are still holding government positions.

(...) I mentioned the assassination attempt against De Gaulle. He was very sorry that it failed." 19

Gilbert did not tell the truth to Szikla when he claimed that his father was a miner, since in reality he was a jeweller. ${ }^{20}$ His depiction of the internal situation in Britain was also a tendentious exaggeration, since those with left-wing convictions were not persecuted at all. He told his host that he was provided with an annual scholarship of 534 pounds and a tworoom flat, plus he earned a further 200 pounds from conducting examinations, and his total annual income was about 1,400 pounds. He was dissembling again, because in 1962, when he was 26 , he bought his first car, ${ }^{21}$ which was a great luxury at the time. He did not mention buying a car to the intelligence agents, moreover he said that he was learning to drive because with a driver's license he was more likely to be picked up as a hitch-hiker. ${ }^{22} \mathrm{He}$ spent two years and three months in military service. He received infantry basic training at the Wiltshire Infantry Regiment, but, due to his knowledge of languages, he was later assigned to the Intelligence Corps. He was later removed from there due to his political views, and finally he spent three months in a penal unit due to his subversive activities in a Cyprus military base at least this is what he claimed to Hungarian intelligence. However, in his official biography he states that when serving in military intelligence "the Soviet Union was my area of study."23 He offers no further details on what his activities were exactly, but it is certain that in this respect he did not tell the truth to Hungarian intelligence.

He related to his Hungarian recruiter that one of his best friends and confidantes was working for the Intelligence Branch of the Treasury. Szikla responded to this proffer as follows:

"I thanked him for his kindness, but added that I would not want to burden him unduly, not to mention that he might get into difficulties. He insisted that that would not happen - not because these were not classified materials, but because he could solve the problem skilfully, his friend was completely trustworthy, and there is no mail censorship in England, which

\footnotetext{
${ }^{19}$ ÁBTL K-184/II, pp. 28-37., Report, 12 September 1961.

${ }^{20}$ See Gilbert's autobiography. Martin Gilbert: In Search of Churchill. A Historian's Journey. p. 4.

${ }^{21}$ In Search, p. 17.

${ }^{22}$ ÁBTL K-184/IV., p. 146. Report to A., 1 May 1962.

${ }^{23}$ www.martingilbert.com
} 
would cause problems. (...) In my judgment "Pártos's" proffer was genuine, and seemed a natural continuation of his behavior and of previous conversations.

His requests:

(...) In the "Filatelia" store I helped him buy a special stamp series, which he intended to use as a special mark of attention on letters to his friends. (...) I took him to an antiquarian, because he has interests in that direction. (...) In my judgment he would be happy to accept such a gift, for example if we were to offer to buy for him the books he selected. (...) He intensely inquired about the promised musical program. He said he would very much like to see this week's performance of "Traviata" at the Opera House. He asked where and how he could cash in travellers checks. I told him that he could do that at the hotel. From the way he asked, I assume that he was running out of the pocket money I had given him, and he was hinting at a further allowance.

\section{His political education}

I combined the visit to the Kilian Barracks, the Kisfaludy alley and the József Attila housing estate with the task of his political education. I explained the conditions of the counter-revolution, the case of Imre Nagy. Later I spoke to him about my own life, about poverty prior to the liberation, and about the events following it. He had no objections, and I believe I managed to influence him significantly, reinforce him politically, and clear up any doubts he may have had in connection with the counter-revolution (he expressed no such doubts to me). ${ }^{24}$

Next day - with a special ministry permit - Szikla took his charge to Dunaújváros (New Town on the Danube), which at that time was still called Sztálinváros (Stalin Town). "In the plant we set up an impromptu meeting with one of the foundry workers. "Pártos" asked him what his salary was. The individual replied that it was 3,500 forints, if he was not performing well, then to "Pártos's" next question replied, that he was paying 50 forints as monthly rent. "Pártos" could hardly believe it, and declared that there was no point in any further questions, these two items of data were most informative. He was deeply impressed by the new machinery in the rolling plant, but he became most enthusiastic when we visited the town's residential area. He declared that he had never seen anything so beautiful, and was particularly moved that such a paradise was constructed for workers of an iron foundry (he also saw the cultural and sports facilities). He summed up his opinion by saying, that if he "could take the inhabitants of the rental slums of Central England's industrial areas to

\footnotetext{
${ }^{24}$ ÁBTL, K-184/II, pp. 46-47.
} 
Hungary and showed them Sztálinváros, next day a revolution would break out in England." On the way home he declared that Sztálinváros made the most lasting impression on him, and he was serious when he was saying, that he would be willing to settle there for the rest of his life." 25

Conditions in Sztálinváros were distressing even for the Hungary of the period, and it is unclear how Gilbert could view them at such variance with reality. Especially since he was generally not sparing with critical remarks. Perhaps he was talking not about what he was seeing, but what he wanted others to see in him?

Peter Szikla sensed a change in the events of 14 September:

"He said that at the IBUSZ they were not sufficiently polite to him, and he also identified some administrative errors. He talked to the office manager, and "instructed" him about these. (This is the second occasion, on which he "instructed." On the previous day he "instructed" the manager of the Astoria Hotel on the subject of the lack of toilet paper and the "laziness" of the waiter. It seems that his critical nature is getting the better of him even in connection with his visit. He has also made some unwarranted and impertinent remarks and demands directed at me and at our itineraries.)

(...)

Remark: From my inquiries and remarks it must be clear that I am more interested in questions of intelligence than the average person. In my opinion, "Pártos" senses this, but does not remark on it." 26

On the 15th they visited the Ferihegy Airport, Szolnok and the "Dózsa's People" agricultural cooperative in Cegléd.

\section{The question of recruitment}

On 16 September Suszta summarized the events so far in a 5-page report. "In the last days - seeing a few small errors - he was critical and demanding. (...) unclear questions do not yet allow his actual recruitment."27 Based on these, he requested an extension of "Pártos's" stay from 10 to 14 days. On the 16th they were at the Workers' Movement Institute, lunch at the Berlin Restaurant, in the evening they watched "Hunyadi László" in the Erkel Theater, and then dined in the Matthias Cellar. They again discussed Gilbert's time spent with military intelligence (MI6). He was inducted in the fall of 1955, he was even sent to officer training

\footnotetext{
${ }^{25}$ ÁBTL K-184/II, pp. 60-61.Report, 14 September 1961. Department II/3-A

${ }^{26}$ ÁBTL K-184/II, Report, 19 September, p. 74.

${ }^{27}$ ÁBTL K184/II, pp. 100-102.
} 
for two days, but after a background investigation he was reassigned to Cyprus, then later to England and West Berlin. Soviet radio-transmissions were monitored here, but he was only assigned to kitchen duties (see his biography, where this is presented differently).

Gilbert had a peculiar attitude towards money. He considered it natural that his hosts would satisfy his various whims. According to Szikla's report, "Pártos" stated that he had changed his mind, instead of a carpet, he would buy a painting. Accordingly, we went to the gallery he had already picked on Bajcsy-Zsilinszki Street. After a lengthy selection process, he settled on two modern paintings and two copper etchings. Their price was about 2,000 forints.

He asked me, how much I could help him with. In accordance with my instructions, I answered that I could not help him at all. I was a poorly paid bureaucrat, I had no savings, and due to expenses in connection with my divorce, I could not even ask for a loan. "Pártos" calculated, that with the travellers checks he had on him, he could muster about 1,500 forints. He asked me whether I could get him the necessary 600 forints. I answered that unfortunately I could not. "Pártos" really liked the pictures he had selected and wanted to get them at any cost, therefore he became demanding. He declared that he could not imagine that I had no way of getting 600 forints. There must be someone at the Chamber of Commerce, or at the organization where I helped out, who would lend this insignificant sum. He wanted only a loan, which he would repay any time in pounds. He bitterly added that he assured us of assistance in far greater matters, and now I was refusing him." [underlined in ink] He suggested that he would approach "Barabás" for a loan. I dissuaded him, saying that it would be an immodest request, since "Barabás" had already spent several thousand forints on his visit. Then he suggested that he would go to the English embassy and request a loan there, if I would not accommodate him. Finally, we agreed that I would check on his request once more, and give him an answer the next morning. ${ }^{28}$

Next day they bought the pictures and had lunch in the "100 Years" restaurant, then visited the Modern History Department of the Eötvös Lóránt University of Sciences and the National Gallery. The gradual recruitment process continued. The only request was to have one more look at one pamphlet against the capitalist states as it was being prepared. To this end they wanted to organize a meeting in Paris in December. The expenses of the trip would "naturally" be reimbursed by Suszta to "Pártos," who accepted this without any particular objection. He particularly liked the idea of a meeting in Paris.

${ }^{28}$ ÁBTL Vol. K-184/II. Report dated 25 September, 1961., 126.o. 
The report dated 25th detailed the program of the $21 \mathrm{st}$ as follows: "The sole purpose of the encounter was to follow up the previous days' preparatory work and discuss the concrete questions in which we would exploit "Pártos's" cooperation. (...) "Pártos" obviously mulled over what I had to say, and responded only after some time. He said that politically he fully understands the importance of the questions he had raised, and also that he could provide important and necessary assistance. Since our last such conversation he had thought a lot about my proposal, and had decided that he must be of assistance, and he will be of assistance. (...) Having discussed the above questions, it was "Pártos" who raised a question, which he introduced by saying, that I should answer only if it was permissible. He wanted to know what the organization was in whose name I addressed my questions to him, how serious, how well founded the organization was, whether the work he would do would be useful, or just a waste of time and effort. I told him that I could not give him a detailed and precise answer, but I considered it natural to give him an outline of our organization. I told him that we were a partly social and only partly official association, whose basic political goal was to suppress fascism, which was reviving in West Germany, and to uncover and punish the Nazi war criminals who were still occupying official positions. To his repeated question I responded that the organization had several hundred actively participating members, who were occupied in specialized areas of the above activities. I myself was active in the area of obtaining information, since this was made possible by my legal occupation (Chamber of Commerce). (...) He asked if our organization had separate offices, and records, where serious work is carried out. I told him that I had already answered this in the affirmative. Finally he asked under what cover organization is the semi-legal organization operating. I responded that we are working as an organization associated with the League of Hungarian Partisans. ${ }^{29}$

After this, Szikla instructed him in basic tradecraft (avoiding wiretaps, self-checks, tailing).

After weighing all circumstances, the recommendation was made on 21 September that he should not be recruited, but exploited as a confidential social contact. His recruitment might be attempted later. For the time being, he was to be tasked - in the form of a request - with obtaining the secret Anglo-German agreements, as well as discovering diplomatic actions directed against the socialist countries, and furthermore he was asked to provide information on English political leaders who had been in favor of closer Anglo-German relations prior to

\footnotetext{
${ }^{29}$ ÁBTL K-184/II, Report, 25 September 1961., pp. 148-150.
} 
the war. Additionally, the preparation of a pamphlet exposing West German diplomats was also planned, and he was tasked with collecting documentation on compromised West German persons. ${ }^{30}$ In the task-plan Szikla supplemented these with questions on the Treasury. The Café Cluny on Boulevard de St Germain in Paris was designated as the next meeting place, and the details of covert contact were fixed.

His room was searched on the $22 \mathrm{nd}$, but nothing was found. The actions of the police must have aroused his interest, because just before his departure, in a manner characteristic of his provocative style, he mailed a letter addressed to "the Hungarian censors," in which he complained about the checking of his correspondence - this suggests that he was completely aware of what was taking place around him.

On 6 October András Tömpe, ${ }^{31}$ chief of the intelligence branch, responded to Suszta's concluding report with criticism that preparation was inadequate, and that the essential question had not been addressed, namely, how suitable would Gilbert be as a "secondary source." In his opinion: "I see no great prospect. It would be useful to look around among his acquaintances and seek direct contacts." Everything points to the fact that even without a face-to-face meeting Tömpe assessed Gilbert's character and his future prospects better than the intelligence officers that had been studying Gilbert for a long time.

Sándor Suszta saw the situation differently: "We noted before his departure that "Carrel"32 [Gilbert - K.U. ] has already identified with the situation. It did not bother him that we regularly discussed intelligence-related questions with him. Rather, we noted that he liked the idea, and he was willing to discuss and assist in this area. The short, silent reflections of earlier days came to an end, and he answered all questions without hesitation. (...) Based on some topical questions we received from the appropriate department, I had him describe in detail his service with the English intelligence organization MI6. "Pártos" readily answered, moreover, he drew paper sketches of the intelligence unit's location and functioning principles." ${ }^{33}$

30 ÁBTL Vol. K-184/II. Recommendation in the "Pártos" case, 21 September 1961., p. 158.

${ }^{31}$ András Tömpe (1913-1971) became a member of the KMP in 1933. Between 1937 and 1939 he fought in Spain and was seriously wounded on two occasions. In the summer of 1942 he went underground to avoid arrest. He received partisan training in Moscow, and in 1946 he was assigned to "diplomatic" duties and became the director of the KGB's South American intelligence activities. He returned to Hungary in 1958. In January 1962 he requested to be relieved as chief of intelligence. In 1971 he committed suicide.

32 Sometime during the development process Gilbert's cover name was changed again, but there is no indication in the documents of when that happened.

${ }^{33}$ ÁBTL Vol. K-184/ III., p. 119. 
Gilbert provided the following names as his acquaintances: Lord Chandon, capitalist and son of the Viceroy of India, Mr. O'Neil, England's ambassador in Helsinki, Joseph Robinson, Foreign Office diplomat, Phillip Hanson, Treasury Intelligence Branch employee. Miss Kaldor, Treasury employee, Mr. Lourdes, Oxford economist, Mr. Deakin, professor and director at St Anthony College, Dedier, a former Yugoslav politician, Mr. Miller, a diplomat of the State Department, Nicholson, former diplomat of the Foreign Office.

On 15 November the evaluation report of his intercepted correspondence was ready. Altogether, he mailed 36 postcards and 12 letters ( 40 percent of these were not intercepted), and received 9 letters. The analysis of correspondence was not positive: "his expressed opinions are not always honest. His statement that he is a Communist is not true." ${ }^{34}$ We can see here, again, that individuals who were observing Gilbert from a certain distance formed a more accurate picture of him than Péter Szikla, who was deeply involved in his recruitment.

\section{The "prospective agent" (?)}

So Gilbert was employed as a "social contact," and - aside from the planned meeting in France - the Service maintained regular contact with him in London. On 26 October 1961 one month after his return home - Nagy was already meeting him in London. According to his evaluation, Gilbert's attitude had not changed; on the contrary, he seemed to be even more of a leftist than earlier. He complained that he did not have 60 pounds to subscribe to the Monitor magazine. - it could be assumed that he was again trying to bum some money. On 24 November 1961 an intelligence officer called Szántó (I had no success in establishing his exact name and position) evaluated the results of the recruitment. He criticized Nagy's preparatory work, but in the end he assessed the case as successful: "from the instruction he received and from the tasks Carrel knows that he is requested to carry out intelligencerelated [emphasis mine - K. U.] tasks. (...) he agreed without reservations, and made several promises to carry out the tasks he had accepted. ${ }^{135}$ This evaluation suggests that Szántó intended to exploit Gilbert in effect as an expanded "social contact," with no formal restrictions.

According to the 6 January 1962 report, Gilbert did not appear at the agreed Paris meeting place. The Ministry of Interior was feverishly working on how to organize the next meeting at a third location, and how to check whether Gilbert had been to Paris at all. A recommendation

\footnotetext{
${ }^{34}$ ÁBTL K-184/III., pp. 148-150. Evaluation Report 15 November 1961.

${ }^{35}$ ÁBTL K-184/III, p. 167. To Comrade Szirtes, London, 24 November 1961.
} 
was made to invite him to Czechoslovakia between 22-23 April, where Péter Szikla could also be present. Meanwhile, the London "residentura" maintained continuous contact with him. On 9 February the Ministry of Interior finally decided on another invitation to Paris, which they intended to get to him by covert means, through a letter franked and mailed in France. However, it was discovered that Gilbert had indicated on a postcard that he could not go to the meeting in Paris.

On 17 May 1962. the Ministry of Interior had to close the case after Sergeant Béla Lapusnyik rode his motorcycle through the border control installations at Hegyeshalom on 9 May and requested political asylum in Austria. Lapusnyik had been assigned to Department II/9 (background checks, surveillance), and had been part of the team following Gilbert during the latter's visit. According to some reports he had also taken a lot of classified material with him. Lapusnyik knew that Gilbert had been under study, and knew that "Barabás" and Szikla were employees of the Ministry of Interior. Lapusnyik, who was under detention by the Austrian Police, was poisoned on 2 June. This also brings up the responsibility of the Austrian authorities. Although he had earlier requested to be taken to the United States embassy (indeed, his departure for the USA was only a question of days), and in his death throes he requested an interpreter, this was not done, and he expired after a lot of suffering on 4 June. State Security could not know what information he had provided, and they could only hope that the "Carrel-case," which had only been marginal for him, was not discussed. Therefore, a recommendation was made to put "Carrel" to rest for a year or two - which, however, did not mean a suspension of contacts with the residentura.

On 7 January 1964 the possibility of reestablishing contact was again brought up in London. The resident, Szalai (Captain László Németh), made the recommendation. Actually, Gilbert had visited Hungary again in the summer of 1963, but State Security did not make contact with him, and, interestingly, Gilbert did not find it necessary to look up his "benefactors," who had spent several months' salary on his earlier vacation. On 15 April 1964 "Péter Szegedi,"36 a reporter stationed in London, submitted a report on Gilbert, who had behaved in a very suggestive manner - so suggestive, in fact, that "Szegedi" suspected a provocation by English counterintelligence. Based on this, on 29 May 1964 the central office prepared the line of approach "Szegedi" was to follow. Major Gábor Pados, ${ }^{37}$ subsection chief, recommended that Gilbert be asked to write on specific subjects, since his book "The

\footnotetext{
${ }^{36}$ His real identity could not be established.

${ }^{37}$ In 1964-1965 Gábor Pados (1929- ) was chief of III/I-1-B (England) subsection, then resident in Ottawa, and between 1977-1989 deputy department chief.
} 
Appeasers" had proven to be politically very useful. ${ }^{38}$ The case was closed for good by a report dated 17 November 1964, according to which Major László Szabó, assigned to subsection III/I-1-B, had had access to the Gilbert file on 3 June 1964, and subsequently defected. "Carrel's" career did not survive being compromised a second time - unlike Gilbert's, who became a confidante of Randolph Churchill, the son of the former prime minister. They had met at Merton College, and soon became co-authors of a book on the prime minister. This opened the doors for him in the highest circles.

\section{Evaluation}

After all these some questions arise. What could Gilbert have known subjectively? What was State Security's evaluation of him? How should we evaluate his involvement?

According to the documents Gilbert must have clearly realized that he was being groomed for intelligence work. Given his outstanding intellectual capacities, it would have been more than odd if he had not realized by the third day of his visit to Hungary at the latest who his hosts were.

From the very beginning British counterintelligence "dangled" its own men to the Hungarian intelligence officers, in order to learn the methods of the residentura and deceive Hungarian intelligence. ${ }^{39}$ These operations became commonplace after 1956, and the Hungarians experienced painful failures. ${ }^{40}$

Reading the documents from today's perspective it is difficult not to believe that Gilbert played the lead role in a "dangle" operation from the very first day - otherwise he would have shown some minimal moral resistance when the Hungarian intelligence officers gave him intelligence tasks. However, the Hungarian Ministry of Interior did not discover the slightest trace of inhibition in his behavior. The fact that Gilbert did not disappear completely reinforces this suspicion: he maintained contact with the Hungarian embassy; had he been frustrated by his experience in Budapest he would have avoided all embassy personnel.

The theoretical foundations for his recruitment seemed sound: (at the time) he seemed to despise his country's political system. Gilbert was already earning a good income, and from the early 1960's he was making giant strides up the social ladder of British high society. His

\footnotetext{
38 ÁBTL K-184/IV., p. 194.

${ }^{39}$ Blau Izidorné "Malvin”, Hans Hellin “Howard”, Szentkuti György “Demeter” ÁBTL O-8-003/I, 352"Dankó" - Reasons for expulsion. Report, Budapest, 1953. május 28.

40 ÁBTL O-8-41/65, Vol. I. "Report on the work of the London residentura in 1958." 8 November, 1958, pp. 13., 59. and O-8-41/65, p. 236. without date or author, "Report on the work of the London residentura between 1 June 1963 and 31 May 1964."
} 
life's work is huge: he wrote 24 monographs and a monumental, 8-volume biography of Winston Churchill, and became a definitive authority.

The world-savior plans he communicated to State Security and his lack of practical helpfulness are remarkable. The fact that he undertook the role of the most famous British prime minister's biographer may suggest that he had re-evaluated his life's priorities. Based on the facts mentioned above, it seems more probable that he was playing a role form the very beginning. This is also suggested by his omission of all information referring to the story related above from texts intended for the public. There are a number of suspicious elements in his visit to Hungary as well: he visited the British Embassy in Budapest on several occasions, saying that he had letters addressed to him there, but he failed to disclose one of his visits to his contact, and deliberately lost the surveillance team. He mailed a large number of serialnumbers letters to various addresses in England, and affixed sarcastic English remarks to some of the envelopes "in the name of censorship" or to the censors. ${ }^{41}$ This, to say the least, is an unusual gesture from a person who declared to his Hungarian hosts that England was a police state and he considered socialism a higher developed system of governance. It is a sad comment on Hungarian censorship that they failed to intercept 40 percent of his outgoing mail. ${ }^{42}$ Gilbert's credibility is also weakened by his visit to the mother of Magda Friedmann in Budapest - which he does not mention in his book on Friedmann, and he never spoke in public about his 1961 visit to Budapest. All of this is interesting because the foundation of his book "Letters" is that he learned about Magda Friedman's family background only after 1990 ... It is more than odd that important biographical facts - known to Gilbert - are absent from a biographical volume.

It is possible that Gilbert himself decided to make fools of his hosts and kept silent about it until now due to modesty. Although it cannot be ruled out completely, it is highly unlikely that Gilbert did not have a principal behind him. And - given Gilbert's intellectual capacities we can exclude the possibility that he was so naive as never to have realized what the game was all about. If he had gotten mixed up in this situation innocently, he would have shown some sign of surprise when his contacts began to bombard him with intelligence-related questions - especially since he had served in military intelligence, and must have known what such an approach must mean. But we can establish one thing as fact: the way he behaved with

${ }^{41}$ For examples see ÁBTL K-184/II, p.94., pp. 130-131., and K-184/III p. 29.

${ }^{42}$ ÁBTL K-184/III, p. 152. Evaluation report on Carell's letters, dated 15 November 1961. Sándor Suszta. 
his hosts in Hungary attests to considerable self-control and courage. We shall never know the truth without access to the secret documents of MI5 and MI6.

In the eyes of Hungarian State Security Gilbert returned home as a recruited agent. Due to his behavior this evaluation soon had to be modified. Strangely enough, state security did not devote a great many resources to seeking his reasons for distancing himself. The disasters that had struck the intelligence organization (the Lapusnyik and Szabó affairs), as well as the incompetence of the personnel involved must have played a role in this. As I mentioned earlier, Gilbert's suspicious behavior had been noted by "Péter Szegedi," but the center paid no attention to it.

Finally, there is no answer to the question of what English counterintelligence made of the Hungarian state security's efforts to recruit Gilbert. He indicated to state security that he was probably considered "politically unreliable" in his own country - this, however, is contradicted by the fact that as a historian he made the fastest and best career possible in Great Britain. It would be rather unrealistic to suppose that he kept from British counterintelligence the Hungarians' attempts to recruit him. And the fact that in the course of his recruitment the Hungarian state security officers did not perceive any surprise or shock suggests premeditated behavior on Gilbert's part. Therefore the version that remains is that Gilbert was an MI5 or MI6 agent from the very beginning, and contacted the Hungarian secret service as part of a double play. This is supported by his meteoric career following his adventure in Budapest. From the British perspective such a plant would have been useful to study the personnel, methods and meeting points of Hungarian intelligence. However, if Gilbert was a British agent, then we may conclude that his far-left views were most likely an act that he put on in order to create a plausible legend for his recruitment. Earlier Soviet intelligence recruited its best sources at the Oxford and Cambridge universities. After their exposure brought about worldwide scandals, it is highly likely that British counterintelligence kept a close watch on these circles. It is also quite likely that they deliberately offered up likely "prospects" to enemy intelligence for purposes of deception, or in order to initiate a double agent operation. If this was not the case, it would be interesting to know how Gilbert reconciled within himself his offer to cooperate with Hungarian Communist intelligence at a time when hanging was still practiced in Hungary. ${ }^{43}$ In his autobiography and during his public appearances he has never spoken of this. The person who has written so much about

\footnotetext{
${ }^{43}$ Imre Nagy and his associates were executed in 1958. The last victims of the 1956 revolution were hanged in 1962. Over 300 people were executed as a result of the revolution.
} 
the importance of discovering and confronting the past has been silent up to now about his own travel to Hungary. 